\title{
Rose Oil
}

National Cancer Institute

\section{Source}

National Cancer Institute. Rose Oil. NCI Thesaurus. Code C66522.

The essential oil extracted from the petals of various rose varieties and species. Rose oil is commonly used in parfumery. 